\title{
Prvorepublikové hydrobiologické stanice aneb Počátky vědeckého výzkumu ryb na Moravě
} ALEŠ VYSKOČIL

Klíčová slova: rybářství - rybníky - výzkum - hydrobiologické stanice - historie - Československo 1918-1945 - Lednice - Velké Meziř́ičí

\section{SOUHRN}

Terénní stanice představují jednu z forem rybářského, resp. rybničního výzkumu. Zprvu soukromé rybářské či (hydro)biologické stanice se v našich zemích začaly objevovat již koncem 19. století, ale k rozkvětu tohoto typu badatelského programu došlo až v průběhu meziválečné éry. V Čechách měl tento typ výzkumu starší a bohatší historii. Na Moravě se rozběhl až ve 20. letech 20. století. Tehdy vznikly dvě terénní stanice, jejichž výzkumy dodnes mají svoji platnost a jejichž působení je možno pokládat za velmi úspěšné. Následující příspěvek ve stručnosti představí počátky rybářského výzkumnictví na Moravě na př́kladu biologických stanic v Lednici a Velkém Meziříčí, které se svým statutem, zaměřením i formou financování od těch českých do jisté míry liší. Velkomeziřričská stanice s badatelským akcentem na rybářskou problematiku se udržela necelých 15 let, lednická hydrobiologická stanice s všestranným prírodovědeckým zaměřením se naopak může pochlubit úctyhodnou dobou fungování.

\section{METODIKA}

O vzniku a vývoji obou hydrobiologických stanic v meziválečné éře se nedochovalo mnoho materiálu. Chybí především institucionální archiv velkomeziřičské stanice. $V$ tomto ohledu jej může jen částečně nahradit fond velkostatku Velké Meziříčí, uložený v Moravském zemském archivu v Brně, kde se nachází např. korespondence majitele a ředitelství velkostatku se zaměstnanci stanice, jejich osobní spisy, popř. agenda spojená se zřízením pstruhárny, třecí stanice pro kapry a plůdkových rybníků [1]. Z archivu lednické stanice, uloženého $v$ Archivu Masarykovy univerzity, se dochovalo pouze torzo (dva kartony) [2]. Rovněž fondy velkostatků Lednice, Břeclav a Valtice $v$ tomto ohledu neposkytují badatelskou oporu. Nedochoval se ani fond př́slušného oddělení Zemského výzkumného ústavu zootechnického v Brně. Pro doplňující studium Ize využít osobní fondy vysokoškolských vyučujících, spojených s fungováním stanic (prof. Emil Bayer, doc. Jaroslav Kř́ženecký, prof. Jan Podhradský). Cenné informace naopak přinášejí př́spěvky publikované ze strany zainteresovaných zaměstnanců v dobovém oborovém tisku, pamětní spisy, výroční zprávy a regionální a celozemský tisk. Z nepočetné sekundární literatury, která se tématu prímo věnuje, je využitelná zejména přehledová práce Rudolfa Hurta o moravském rybníkářství [3]. Obecně platí, že více pozornosti bylo v odborné produkci věnováno stanici $v$ Lednici, proto je $v$ tomto textu mírně akcentován príběh druhé zmíněné.

\section{ÚVOD}

Rybářské výzkumnictví má poměrně dlouhou historii. Počátky soustavného rybářského a hydrobiologického výzkumu v českých zemích je možno hledat v období před více než 100 lety. Jsou spojeny především s aktivitami Antonína Friče, profesora na pražské české univerzitě, a rovněž tak s vědeckým prístupem k chovu kapra ředitele třeboňského rybničního velkostatku Josefa Šusty. $\checkmark$ souvislosti s vývojem badatelské metodiky se stále více uplatňoval kombinovaný teoreticko-praktický prístup k výzkumu a jedním z jeho výrazů bylo budování terénních stanic. Za tou vůbec nejstarší je třeba hledat právě Antonína Friče, který se touto myšlenkou inspiroval na príkladu prímořských výzkumných stanic. Od června 1888 byla mobilní neboli "létací" zoologická stanice, jak ji sám Frič nazýval, dislokována u Dolnopočernického rybníku (dnes Praha), kde byly zkoumány vlivy počasí, teplotní poměry, rybniční plankton a oživení dna a sledovány obsádky rybníků. Následně stanice „přelétla“ ke Kačležskému rybníku u Jindřichova Hradce, po nějaký čas působila při Černém a Čertově jezeru na Šumavě, aby nakonec do roku 1925 dosloužila u Poděbrad, při slepém rameni Labe zvaném Skupice. Mezitím (1892) se Fričovi podařilo u břehu Dolnopočernického rybníku u Běchovic realizovat stálou stanici (fungovala do první světové války). V jižních Čechách rozvíjela od počátku 20. století (1904) činnost jiná výzkumná rybářská stanice, spojená s profesorem českobudějovické rolnické školy Vácslavem Josefem Štěpánem. Ten se orientoval na problematiku zpracování ryb, patologii ryb, rozbory potravy a krmiva a poradenství. Když byla v roce 1920 ve Vodňanech zřízena první (střední) rybářská škola u nás a Štěpán se stal jejím ředitelem, otevřel při ní Výzkumnou stanici rybářskou a hydrobiologickou coby nástupce své českobudějovické soukromé iniciativy. V roce 1921 vznikl centrální Výzkumný ústav rybářský a hydrobiologický v Praze a k témuž roku pod něj přešla i vodňanská stanice (v letech 1928-1934 presídlená do Libějovic, poté začleněna pod vodňanskou školu). Tehdy také státní výzkumný ústav získal velmi cenný „úlovek“ postátněním výzkumné stanice $v$ Doksech při Máchově jezeře. Ta byla otevřena již počátkem 20. století jako soukromý podnik a mezitím pod vedením Dr. Viktora Langhanse, specializujícího se na studium výživy kapra, podřizená zemědělskému oddělení pražské německé techniky v Děčíně-Libverdě. V letech 1925-1931 provozoval centrální ústav také terénní pracoviště v Chlumu u Třeboně. Od roku 1932 se terénní hydrobiologický výzkum pod patronátem ústavu a zaměřený na pstruhařství prováděl také ve slovenském Liptovském Hrádku, následně také v Užhorodě. A postupně se objevovaly další stanice. Inventár zchátralé Fričovy „létací" stanice našel své další uplatnění na terénní stanici u rybníka Velký Pálenec v rámci Inářsko-blatenské rybniční soustavy, která byla zřízena v roce 1925 dílem docenta zoologie na Univerzitě Karlově Karla Schäferny a správce Inářského velkostatku Theodora Mokrého a která funguje jako vědecké a pedagogické pracoviště Prírodovědecké fakulty Univerzity Karlovy dodnes [4-8]. 


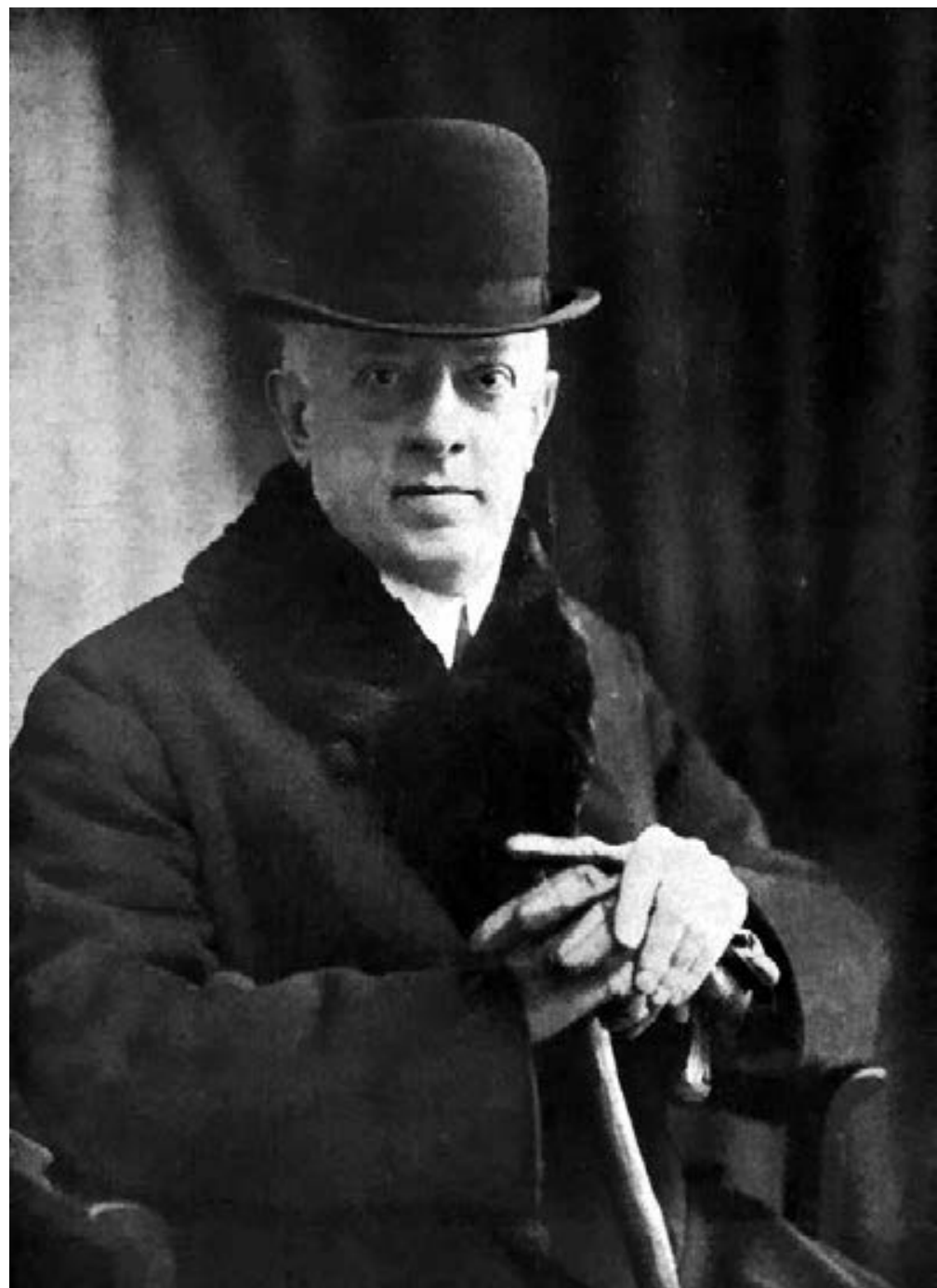

Obr. 1. František Harrach, zakladatel a majitel stanice (zdroj: Státní okresní archiv Ždár nad Sázavou, fond Sbírka soudobé dokumentace Velké Meziřičí)

Fig. 1. František Harrach, the founder and owner of the station (source: State district archives Ždaár nad Sázavou, group Sbírka soudobé dokumentace Velké Meziříčí)

Během krátké doby vykrystalizovala v Čechách sít stanic, v prevážné většině nakonec subvencovaná státem. Na Moravě se výzkum soustredil pod rybářskou a hydrobiologickou sekci Zemského výzkumného ústavu zootechnického v Brně. Teprve po ustavení Vysoké školy zemědělské (dále jen VŠZ) v roce 1919, kterou personálně zaštítili odborníci z pražských škol a táborské akademie a zř́zení dvou terénních stanic v Lednici a Velkém Meziříčí se rybářský a hydrobiologický výzkum plnohodnotně rozvinul. Velkomeziřiččá stanice byla ryze soukromým projektem, čímž se odlišovala od všech ostatních. Svým úžeji koncipovaným badatelským a zároveň praktickým zaměřením se blížla státem podporovanému vodňanskému ústavu. Lednická stanice fungovala jako edukativně-výzkumná instituce s pestrým kofinancováním, mimořádnou šiři přírodovědného záběru odpovídající podobně koncipované stanici v Doksech. Se staničním výzkumem jsou spjaty klíčové osobnosti rybářské a hydrobiologické vědy první poloviny 20. století (Langhans, Kostomarov, Dvořák, Podhradský, Čerňajev, Kříženecký, Mokrý atd.), vzájemně propojující oblast vysokého školství, vědeckých ústavů, spolků a oborových sdružení, a také špičkový základní výzkum s vítaným aplikačním potenciálem.

\section{RYBÁŘSKO-HYDROBIOLOGICKÁ STANICE FRANTIŠKA HARRACHA VE VELKÉM MEZIŘíČí}

Na soukromý statut instituce odkazuje již oficiální název. Její vznik a následnou činnost totiž umožnil donátor ústavu, majitel velkomeziříčského velkostatku hrabě František Harrach [9] (obr. 1). Zřízení stanice předcházel několikaletý kontakt zaměstnanců velkostatku s rybářskými odborníky ze sekce pro plemenářskou biologii při Zemském výzkumném ústavu zootechnickém v Brně, kterým velkostatek dodával v letech 1923-1925 na pokusy tamní kapři plůdek. Vzhledem k dlouhodobému pasivnímu výnosu rybničního hospodaření velkostatku, které mělo v roce 1925 schodek 50000 korun v souhrnu na všech 58 rybnících, bylo dohodnuto ředitelem Harrachova velkostatku, lesním radou Václavem Škvařilem a Jaroslavem Kř́ženeckým, přednostou zmíněného výzkumného ústavu a zároveň docentem na VŠZ, započetí monitoringu hydrobiologických poměrů rybníků za účelem reorganizace a racionalizace hospodaření; konečně jednou z motivací Františka Harracha bylo docílit vyšší rentability hospodaření na majetku zmenšeném $v$ důsledku pozemkové reformy. $V$ létě 1926 byly zprovozněny laboratoře $v$ úredních prostorách velkostatku a terénní stanice u Netína a během dvou let byly velkostatku předloženy výsledky pozorování působení prostoru na růst plůdku a jeho jakost a vypracován plán rybničního hospodaření opřený o důkladná vědecká bádání. Na jeho základě vykázalo rybniční hospodářství již v roce 1929 nárůst produkce o 220 \% při aktivní bilanci 180000 korun. Tento výrazný posun nicméně nebylo možné srovnávat s největším a nejvýkonnějším rybničním hospodářstvím na Moravě, resp. v Československu - lednickými rybníky - s obratem půl milionu korun.

Štastné sepětí základního a aplikovaného výzkumu umožnilo další fungování stanice, kterou již koncem roku 1928 majitel velkostatku prohlásil za stálou. Přednostou stanice byl jmenován Jaroslav Krríženecký, jeho zástupcem Dr. Ing. Boris Kostomarov, profesor na Státní rybářské škole ve Vodňanech (1926-1934) a od roku 1935 také přednosta hydrobiologické stanice v Liptovském Hrádku a později v Užhorodu, jehož účast si na velkostatku vymínil doc. Kříženecký, a stálou odbornou silou na stanici Dr. Ing. Vasilij Čerňajev (oba absolventi VŠZ z řad poválečné ruské emigrace), který figuroval ve stavu zaměstnanců velkostatku a byl správcem stanice a později (1932) také správcem rybničního hospodaření. Kromě zmíněných, kteří se podíleli již na prvotních výzkumech, přibyl ke stabilním zaměstnancům v roce 1929 Dr. Willy Nowak; na výzkumu se podílel také Dr. Jan Podhradský a celá řada externistů a dobrovolníků. Stanice, slavnostně uvedená do provozu v červnu 1930, byla na svoji dobu velmi dobře vybavena a finančně zajištována ze strany velkostatku každoroční dotací, at’ se již jednalo o platy zaměstnanců, vlastní prostory pro chemickou a biologickou laboratoř (obr. 2), prístrojové vybavení, knihovnu, ale také např. možnost využívat pro práci v terénu motocykl. František Harrach poslání stanice komentoval mimo jiné těmito slovy: „Prál bych si, aby tato stanice byla v živém styku s vědeckými institucemi a zároveň i pod jejich jistou kontrolou. Z toho důvodu jsem se rozhodnul vytvoriti pro stanici Poradní sbor ze zástupců našich vysokých škol a vědeckých a odborných organisaci." [1]. Konstituováním vskutku reprezentativního poradního sboru pro stanici, do kterého byli vysláni zástupci př́slušných pražských a brněnských vysokých škol, organizací a spolků, a to českých i německých, zajistilo stanici náležité místo v oborové komunitě a možnost prezentovat a konfrontovat výsledky na domácích i zahraničních odborných fórech.

Volba velkomeziřičské rybniční soustavy pro vědecký výzkum byla výhodná nejen pro pochopení mecenáše, jenž byl sám lesnickým a zemědělským odborníkem, ale také kvůli její struktuře. Rybniční hospodářství s 58 rybníky různé velikosti a s celkovou zatopenou plochou asi 265 ha se rozkládalo na území téměř celého okresu Velké Meziríčíi. Vodní plochy se nacházely ve vyšších a chladných nadmořských výškách (425 až 650 m n. m.), často od sebe velmi vzdálené, byly zde zastoupeny rybníky zčásti i zcela uzavřené větrům a napájené chladnými lesními potoky, rybníky zcela otevřené, avšak odlišné lokalitou, charakterem vody, půdními podmínkami, flórou i faunou, rybníky napájené toky nebo 

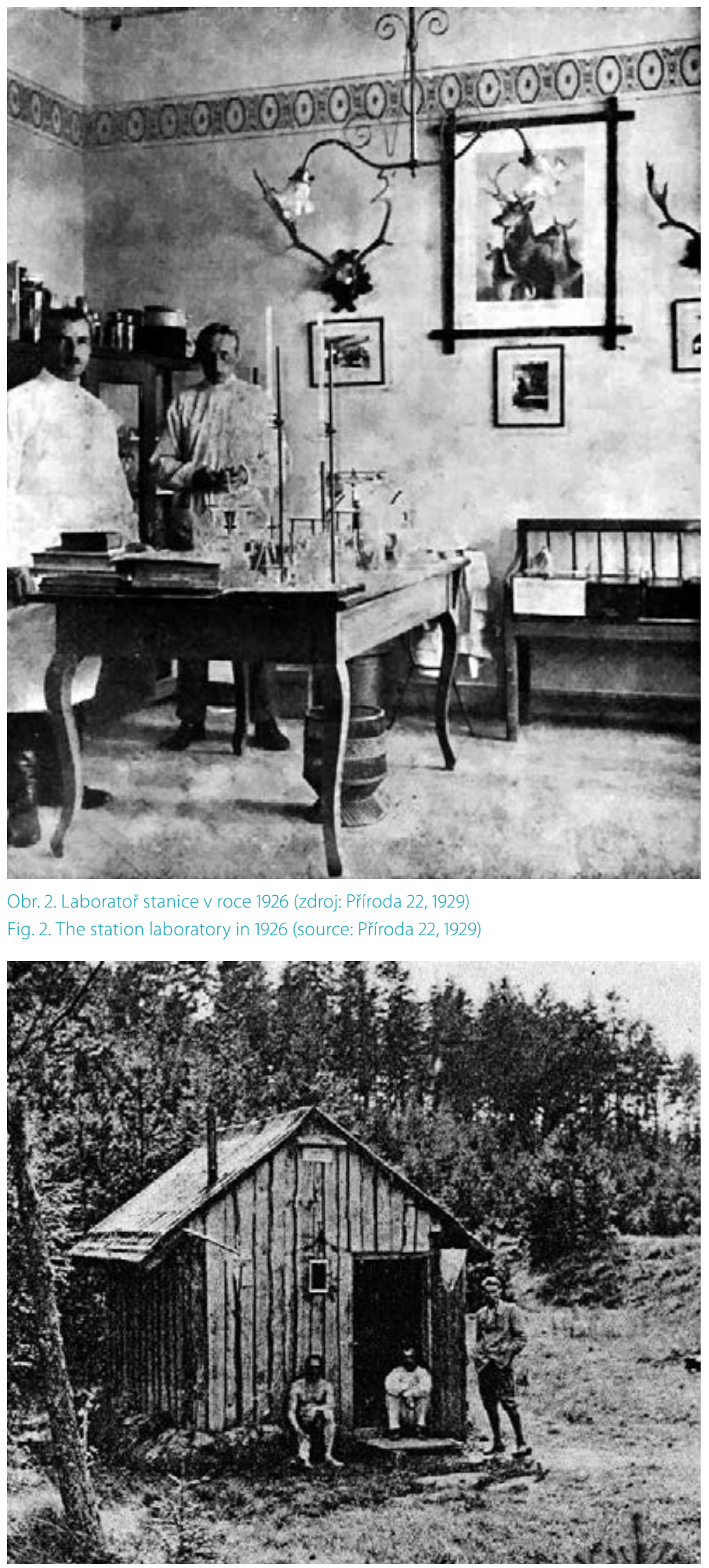

Obr. 3. Terénní bouda pod hrází rybníka Vrkoč (zdroj: Príroda 22, 1929)

Fig. 3. The field cabin below the dyke of the fishpond Vrkoč (source: Príroda 22, 1929)

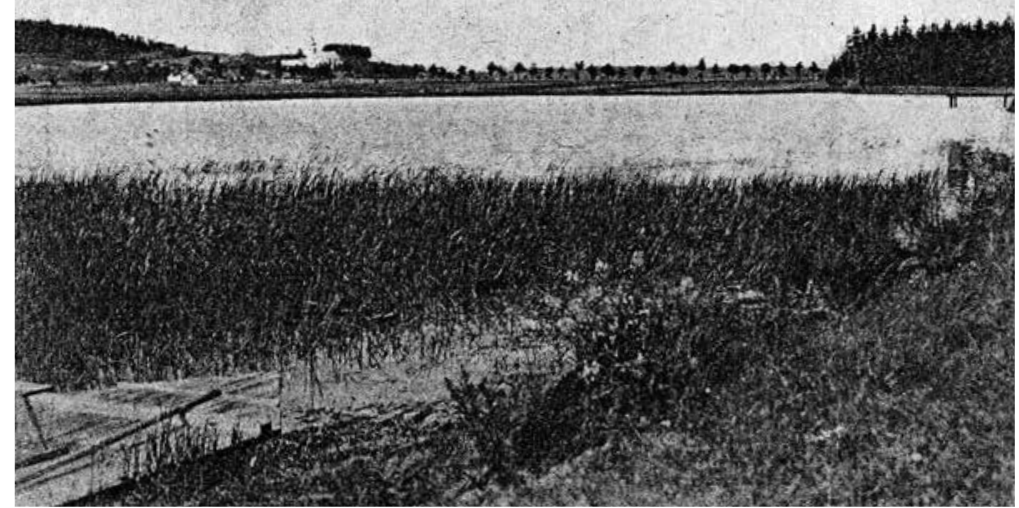

Obr. 4. Rybník Vrkoč ve 30. letech 20. století, v pozadí vesnice Netín

Fig. 4. The fishpond Vrkoč in the 1930's, village Netín in the background

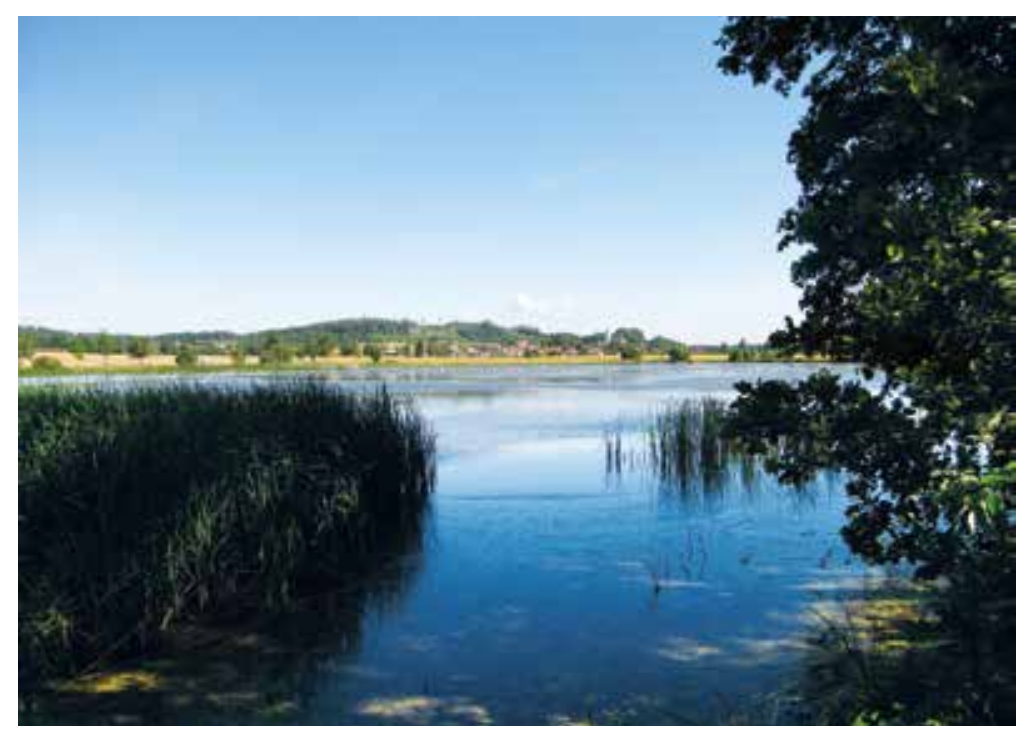

Fig. 5. The same view today

srážkami, přičemž nebeské rybníky převažovaly. Pestrost hydrobiologických podmínek dodávala zdejším analýzám širší než jen lokální význam. Centrem výzkumu se stala oblast Netínského rybníku, rybníku Vrkoč a čtyř pokusných rybničních líhní umístěných mezi nimi (při obci Netín mezi Měřínem a Velkým Meziříčím), kde stála zmíněná terénní laboratoř (obr. 3). Ke stálým pokusům bylo zvoleno 14 rybníků, reprezentující jednotlivé typy. V nich se zkoumala veškerá vodní fauna a flóra, stejně jako ta vyskytující se v jejich okolí. Hlavní akcent byl kladen na chov kaprů (méně již štiky, lína, candáta a pstruha duhového), studovány byly také prírodní a umělé podmínky výskytu raka, který představoval specifikum velkomeziř́čského rybničního hospodaření. Silný potenciál zde mělo také ornitologické bádání (obr. 4 a 5).

Pracovní program stanice sledoval hned několik linií. Předně měla sloužit běžným potřebám rybničního hospodářství velkomeziříčského velkostatku, ale její okruh zájmu byl širší a měla ambici stát se vědeckým centrem nejen západomoravského prostoru, ale otevřeným všem badatelům. Provádět se zde měly 
výzkumy ve všech oblastech rybářství a rybníkářství při zachování naprosté badatelské volnosti. Unikátnost této stanice $v$ rámci celé republiky spočívala v jejím výjimečném soukromém statutu a v terénní lokalizaci uprostřed hospodářského prostoru se silným důrazem na praktické využití poznatků. Tímto se odlišovala od hydrobiologické stanice v Lednici, která se zaměřovala více na teoretický výzkum a zároveň byla školícím pracovištěm studentů brněnských vysokých škol. Harrachova stanice tak ve své době byla jediným podnikem na Moravě, který naplňoval politiku centrálního státního rybářsko-hydrobiologického výzkumného ústavu budujícího lokální stanice se specifickým výzkumným programem, s úspěchem aplikovatelným v konkrétních hydrobiologických podmínkách [3, 10-19] (obr. 6).

Badatelské zaměření stanice bylo velmi široké, zkoumal se vztah růstu kapřího plůdku s ohledem na množství potravy a velikost životního prostoru, složení planktonu, vliv teploty vody, vztahy mezi plyny ve vodě, tvorba jiker, líhnutí a růst raných stádií, plůdku, násad a tržních ryb. Vývoj a růst po stránce anatomické, histologické a biochemické byl studován mj. také na proslulé kapři produkci sousedního moraveckého velkostatku baronské rodiny Nádherných z Borutína. V souvislosti se studiem růstu kapra byly prováděny také výzkumy jeho exteriéru, a to i s ohledem na jeho tržní užitnou hodnotu. Zkoumání byl podroben nejen místní tzv. moravský horácký typ (vysokohřbetý lysec), ale také produkce ostatních významných rybničních hospodářství, včetně těch jihočeských v Hluboké nad VItavou a Třeboni. Praktickým účelem těchto rozsáhlých výzkumů bylo vytvoření metodiky pro plemenitbu kapra (směrnice pro výběr generačních ryb) a docílení jejich největší užitkové hodnoty s ohledem na variabilitu teritorií. Tento celostátní monitoring linií kapra vedl k doplnění a opravě stávajícího systému měření kapra a stanici zajistil proslulost i v mezinárodních odborných kruzích. Během 30. let byly dále prováděny plošné fyzikálně-chemické analýzy rybníků, konány pokusy s přihnojováním vody (superfosfát) a vápněním, zkoumal se vliv slunečního záření a obecně počasí na rybniční vody. V roce 1934 se podařilo zrídit moderní sádky pod zámkem ve Velkém Meziřićí a započal se projekt „velkolepé“ pstruhárny. Mimo to se stanice věnovala studiu odpadních vod a otázkám znečištování vod průmyslovými závody (horní Vltava, Balinka a Oslava na Velkomeziř́č́sku) s ohledem na dopady biologické, hygienické i národohospodářské. Otevřenost stanice vưči veřejnosti symbolizoval již v roce 1929 uspořádaný rybářský kurz (první od roku 1918 na Moravě) a rozličné propagační akce [1, 19-21].

Teoretické i praktické badatelské výstupy zaměstnanců stanice byly publikovány v odborných časopisech domácích (Věstník Československé akademie zemědělské, Sborník Československé akademie zemědělské, Československý zemědělec, Československý rybář, Velkostatek, Příroda, Rybářský věstník, Věda prrírodní, Sborník Vysoké školy zemědělské v Brně, Der deutsche Fischer aj.) i zahraničních (německých Fischerei-Zeitung, Zeitschrift für Fischerei und deren Hilfswissenschaften, francouzského Bulletin Français de Pisciculture nebo polského Przegląd Rybacki). Během několika let uveřejnili jednotliví pracovníci stanice neuvěřitelných více než 100 odborných článků, ve kterých se mimo jiné věnovali i popisu a porovnání vývoje rybářské a hydrobiologické vědy v zahraničí (SSSR, Polsko, Rumunsko či Bulharsko). Svými výstupy si Harrachova stanice, i přes nedlouhé trvání, získala mezinárodní renomé. Její výstupy představují v mnoha ohledech trvalou hodnotu dodnes.

Stanice ke konci roku 1938 omezila svůj provoz. Oficiálně se tomu stalo z úsporných důvodů, svoji roli však bezesporu sehrálo i úmrtí zakladatele hraběte Harracha v květnu 1937 a komplikované dědické řízení. Ředitelství velkostatku původně počítalo pouze s dočasným útlumem. Dochovaná korespondence naznačuje jakési spory mezi správou velkostatku a stanicí ohledně nenaplňování základního poslání stanice sloužit prímým provozním potřebám rybníkářství v posledních letech. Nabízený presun stanice do Užhorodu, kde působil Dr. Kostomarov, Harrachova dcera a dědička Josefa odmítla. V letech 1939 a 1940 vyšlo ještě několik studií, stanice provizorně fungovala, ale z finančních důvodů nebylo možné podporovat stálý odborný personál (Dr. Nowak se

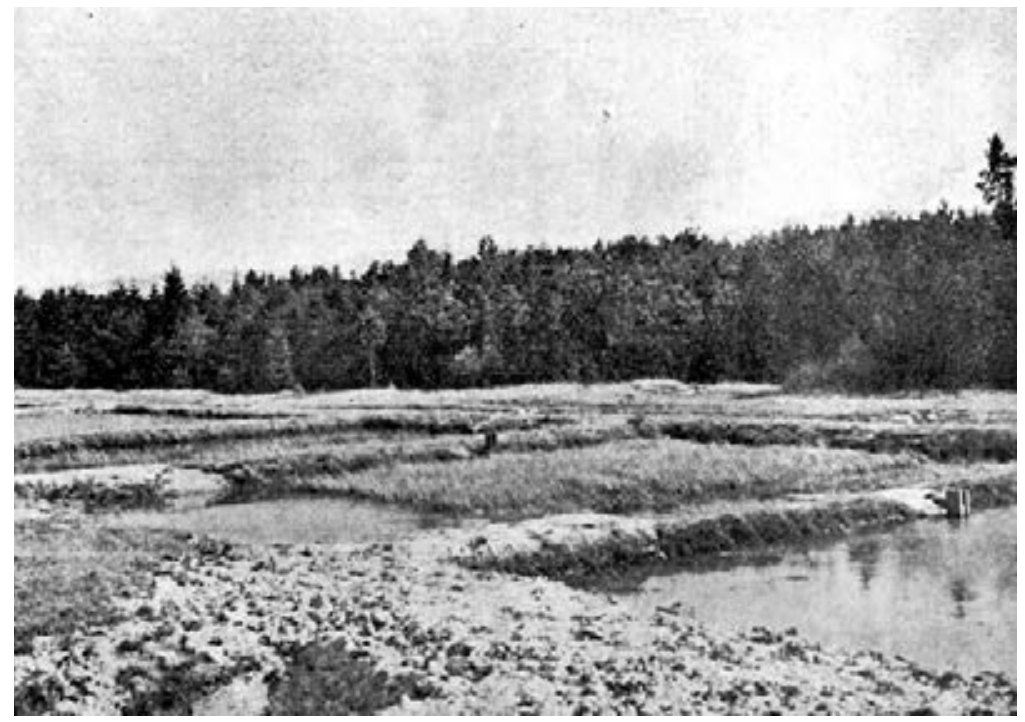

Obr. 6. Pokusné líhně pod hrází Vrkoče (zdroj: Příroda 22, 1929) Fig. 6. The hatcheries below the dyke of the fishpond Vrkoč (source: Príroda 22, 1929)

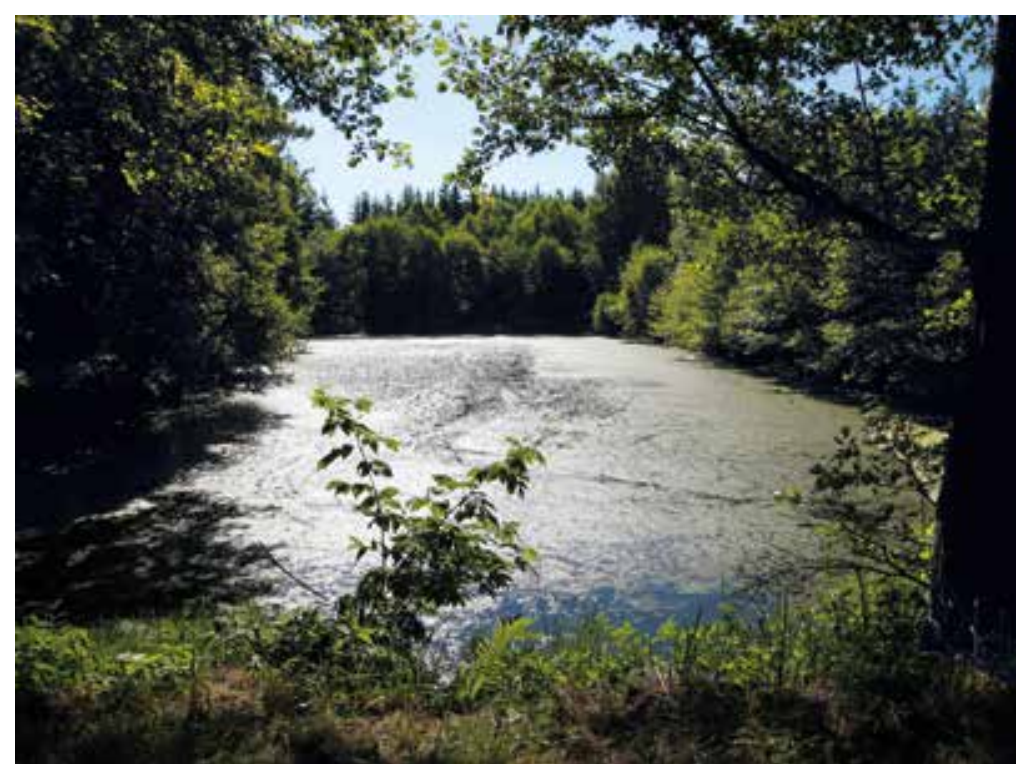

Obr. 7. Jediný dodnes dochovaný pokusný rybníček

Fig. 7. The one and only surviving hatchery

nuceně presunul do německého Königsbergu). Stanici v její původní podobě se nakonec při životě udržet nepodařilo. Harrachovy rybníky převzalo po roce 1948 Státní rybářství Velké Meziř́čí, které využívalo i staniční terénní boudu a pokusné rybníčky-líhně při hrázi rybníku Vrkoč. Jeden z nich se dochoval dodnes, využíván byl jako líheň až do konce 70. let 20. století [1, 22, 23] (obr. 7).

\section{BIOLOGICKÁ STANICE VYSOKÝCH ŠKOL BRNĚNSKÝCH V LEDNICI}

Jihomoravská stanice se od té předchozí v mnohém liší. Její zaměření bylo především všestranně prírodovědné s významným podílem ornitologického výzkumu. Navíc sloužila vysokoškolskému výukovému programu. Splňovala tak kombinaci vzdělávací a badatelské instituce s akcentem na základní formu výzkumu. Její existence je úzce spojena s prof. Emilem Bayerem, ředitelem zoologického ústavu VŠz. Na potřebnost založení stanice později vzpomínal 
prof. Bayer takto: „Plánem, dociliti zrízení biologické výzkumné stanice na Moravě, zabýval jsem se již dávno, téměř od počátku svého príchodu na Moravu [Bayer byl jičínským rodákem a absolventem Filozofické fakulty v Praze - pozn. autora], jakmile jsem začal podrobněji poznávati dosavadní stav prírodovědeckého prozkoumávání země a jeho nedostatky. Uvažoval jsem o možnosti zř́diti alespoň nějakou primitivní výzkumnou staničku, sháněl jsem prostředky, jak toho dosáhnouti, a hledal ovšem príhodné misto; již v letech 1902-3 byla moje pozornost upoutána neobyčejnými prírodními poměry jihomoravského územímezi Breclavou a Mikulovem." [24, 25].

K realizaci nápadu došlo až v roce 1922, tedy $v$ době, kdy v Brně již tři roky existovaly tři české vysoké školy (Přírodovědecká a Lékařská fakulta Masarykovy univerzity, Hospodářská a Lesnická fakulta VŠZ a Vysoká škola zvěrolékařská), z nichž každá měla své biologické ústavy, a potřeba zřízení terénní stanice byla více než naléhavou. Žádný podobný podnik na Moravě dosud neexistoval. Prof. Bayer přitom upozorňoval, že evropské státy tou dobou vydržovaly již bezmála 60 hydrobiologických stanic (mořských a sladkovodních) a jejich smysluplnost dokazuje ustavení Mezinárodní společnosti pro teoretickou a užitou hydrobiologii. Stanice byla od počátku zamýšlena jako pedagogicko-výzkumná instituce a jako taková musela mít posvěcení ministerstva školství. To zř́zení stanice povolilo v březnu 1922 a tři měsíce na to badatelé dostali k užívání budovu lichtenštejnského loveckého zámečku č. p. 437 (tzv. Rybniční zámeček) situovanou na severním břehu Prostředního rybníka. Stanice se nacházela v blízkosti čtyř velkých rybníků, z nichž Nesyt je na Moravě vůbec největší. Emilu Bayerovi se podařilo pro svou ideu získat tehdejšího majitele lednicko-valtického velkostatku Jana II. knížete z Lichtenštejna, který mu dokonce dal vybrat mezi Hraničním a Rybničním zámečkem. Výzkumné stanici bylo v zámečku přiděleno celé první patro se třemi místnostmi a správa velkostatku souhlasila s tím, aby její zřízenec, bydlící v přizemí, zároveň príijal úlohu hlídače celého objektu. Nájemné bylo stanoveno na ročních 400 korun a smlouva byla v pravidelných třiletých intervalech prodlužována. Majitel velkostatku si podmínil, že chod stanice nesmí v žádném prípadě omezovat chov ryb, dále že odběr vzorků a ryb je možný pouze se souhlasem správy, a výslovně bylo zmíněno prání, aby stanice fungovala, pokud možno, jako všeobecně prístupné vědecké pracoviště. Oproti stanici ve Velkém Meziríčí, jejiž vybavení a chod byl financován majitelem velkostatku, zde bylo nezbytné o podporu žádat ministerstvo a další instituce. Pravidelné a dlouhodobé subvence na zařízení stanice (pracovny, laboratoře, obývací pokoje), prístrojové vybavení, provozní režii i platy zaměstnanců pricházely zejména od Zemského výboru v Brně, Masarykovy akademie práce a Akademie věd v Praze. Knižní a časopisecký fond byl mimo jiné doplňován formou výměny s oborovými pracovišti v zahraničí (USA aj.), především díky kontaktům a renomé prof. Bayera. Z dochovaných materiálů týkajících se fungování a finančního zajištění stanice plyne, že přidělované prostředky, snad s výjimkou ministerských rádných dotací, nebyly nárokového charakteru a svým objemem stabilní a že představenstvo stanice bylo nuceno $v$ této záležitosti pravidelně komunikovat s relevantními institucemi, a mimo to vést velmi podrobné výkaznictví, což nepochybně elán pracovníků podlamovalo.

Staniční výzkum se soustředoval především na ornitologická pozorování (stanice disponovala na svou dobu velmi kvalitními dalekohledy), entomologii a hydrobiologické bádání (studium planktonu, chemického složení vody), které bylo umožněno používáním vlastních člunů. Studium rybniční mikroflóry a mikrofauny, typologicky a strukturou ovlivněné intenzivním hospodářským využíváním rybniční soustavy, muselo respektovat primární pravidla nastavená vlastníkem velkostatku. Mimo rybníky zaměstnanci monitorovali také inundační terén Podyjí s průtočnými i slepými rameny, bažinami, tůněmi i umělými kanály. Rozlehlá a pestrá krajina Lednicko-valtického areálu poskytovala ideální objekt pro regionální zoologický i botanický výzkum, prováděla se zde pozorování meteorologická, geofyzikální, pedologická a celá řada dalších. Recipročně se předpokládalo možné využití vědeckých poznatků pro zkvalitnění rybničního a rybářského hospodárství Lichtenštejnů. Ve své době byla stanice pestrostí výzkumných aktivit a kvalitou výzkumu srovnatelná pouze s hydrobiologickou stanicí v Doksech navázanou na německé univerzitní prostředí v Praze. Stálou stanici v Doksech, nejkvalitněji organizovaný pedagogicko-výzkumný a nejdéle kontinuálně působící ústav v českých zemích, Ize označit za vzor, podle něhož vytvořil Emil Bayer moravský pendant $[2,24,26]$.

Stanice sloužila jako pomocný vědecký ústav pro všechny tři zmíněné české vysoké školy, odtud také její název Biologická stanice vysokých škol brněnských. Správní kuratorium stanice, zodpovědné za její organizaci, chod a výzkum, bylo složené z předních zástupců jednotlivých škol. V čele kuratoria stál ředitel stanice prof. Bayer. V roce 1924 se podařilo systemizovat jedno stálé místo asistenta stanice, kterým se stal Ing. Alexander Bajkov a po jeho odchodu do Kanady Ing. Jindřich Zapletálek a krátce František Unzeitig. Podobně jako v prípadě Velkého Meziříči i zde sezonně hojně působili ruští učenci.

Velký problém stanici nastal na podzim roku 1938, kdy se ocitla mimo nově stanovené hranice Československa a kdy bylo nezbytné odvézt drahý a nenahraditelný inventár̆, včetně knihovny, k čemuž byl získán souhlas vojenské a politické správy. Provizorně byl uskladněn v budovách VŠz. Činnost stanice se ani poté nezastavila, výzkumy probíhaly $v$ rámci jednotlivých ústavů vysokých škol, a to až do jejich uzavření. Od června 1939 byla stanice přemístěna na školní lesní statek do Křtin, náležící taktéž pod VŠZ, a fungovala po celou dobu války pod názvem Česká biologická stanice ve Křtinách. Za roční nájemné 200 korun mohla využívat tři místnosti na zámku a lovecký zámeček v Jedovnicích coby filiální hydrobiologickou pracovnu. V roce 1946 se stanice prestěhovala do svého původního objektu, který však byl poškozen válečnými událostmi. Nedotčena naopak zůstala většina mobiliáre detašovaného ve křtinském azylu. Nová smlouva se správou státních statků Valtice byla stanovena na šest let, do roku 1952, za stejných podmínek jako dřive. To již zesnulého prof. Bayera v čele stanice vystřídal prof. Josef Kratochvíl a v čele kuratoria prof. Josef Podpěra. V roce 1952 byla stanice po dohodě všech zainteresovaných stran převedena pod správu VŠZ jako součást katedry pro živočišnou výrobu a funkcí vedoucího pověren šéf katedry prof. Kostomarov, první vysokoškolský profesor rybářství a hydrobiologie u nás, profesně spojený s vědeckou činností bývalé stanice ve Velkém Meziřičí. Tím začala nová éra v dějinách stanice, která se uzavřela teprve nedávno (2013) $[2,27,28]$.

Mimo tyto dvě klíčové instituce terénního výzkumu vznikly na Moravě i další, např. Zemské výzkumné stanice rybářské a hydrobiologické v Hodoníně a ve Studenci, kde má dnes detašované pracoviště Ústav biologie obratlovců Akademie věd.

\section{ZÁVĚR}

Terénní stanice $v$ Lednici a ve Velkém Meziřićí představovaly $v$ meziválečném Československu významná centra rybářského a hydrobiologického výzkumu na Moravě a svými výsledky si získaly mezinárodní renomé. Obě byly personálně propojeny s tehdejšími významnými vzdělávacími a badatelskými ústavy. Ve Velkém Meziřićí se výzkum orientoval na exteriér kapra z hlediska jeho potravinářské, užitkové či tržní hodnoty, na zkvalitňování produkce kapř́ho plůdku a jeho růstových parametrů. Akcent na „aplikační" rovinu staničního výzkumu úzce souvisel se soukromým statutem instituce. Naproti tomu badatelské zaměření lednické stanice bylo širší, obsáhlo celé spektrum odnoží přírodovědného oboru. V rámci rybářského výzkumu se zde sledoval zejména vývoj přirozené potravy ryb a vliv hnojiv na její rozvoj. Lednická stanice fungovala v úzké součinnosti s vysokoškolským prostředím a měla statut edukativně-výzkumného ústavu. Chod velkomeziř́čské stanice byl utlumen v letech 2. světové války, na její činnost později navázalo Státní rybářství Velké Meziříčí. Lednická stanice fungovala od roku 1952 jako integrální součást VŠZ v Brně. 


\section{Poděkování}

Článek byl zpracován s finanční podporou projektu DG16P02M032 výzvy NAKI II Ministerstva kultury ČR "Neinvazivní a šetrné postupy řešení kvality prostředí a údržby vodnich prvků v rámci památkové péče".

\section{Literatura}

[1] Moravský zemský archiv v Brně, fond F 209 - Velkostatek Velké Meziříčí, inv. č. 562, karton 176 a 177, inv. č. 574, karton 197.

[2] Archiv Masarykovy univerzity v Brně, fond A 12 - Biologická stanice českých vysokých škol Lednice (1922-1951), karton 1 a 2.

[3] HURT, R. Déjiny rybnikářství na Moravě a ve Slezsku. 2. díl. Ostrava: Krajské nakladatelství v Ostravě, 1960,324 s.

[4] POKORNÝ, J. a kol. České rybníky a rybářství ve 20. století. České Budějovice: Rybářské sdružení České republiky 2015, $336 \mathrm{~s}$.

[5] JANKO, J. Hydrobiologie v českých zemích: plod vlastenectví, praktických potřeb anebo součást imanentního vývoje vědeckého poznání? Rozpravy Národního technického muzea v Praze, 2006, roč. 200, s. 123-127.

[6] 50. let rybářského školstvíve Vodňanech. Vodňany: Střední rybářská technická škola, 1970, 128 s.

[7] SVOBODA, E. Naše rybářství v přehledu. Zemědělský archiv, 1932, roč. 23, s. 410-420.

[8] HAHN, J. Literatura zoologická. In: Československá vlastivěda. X. díl. Osvěta, Praha: Sfinx, 1931, S. 484-516.

[9] NOVOTNÝ, G. Velkostatkář a lesník JUDr. František Maria Alfréd Harrach. Západní Morava, 1999, roč. 3, s. 287-295

[10] KOSTOMAROV, B. Rybářsko-hydrobiologická stanice ve Velkém Meziříčí. Príroda, 1929, roč. 22, S. 341-351.

[11] KŘlZŽENECKÝ, J. Nová výzkumná stanice rybářsko-hydrobiologická založená Fr. Harrachem ve Velkém Meziříčí na Moravě. Československýr rybár̆, 1930, roč. 10, č. 8-9, s. 103-106.

[12] Rybářsko-hydrobiologická stanice Františka Harracha ve Velkém Meziřííi na Moravě. Organizace Zařizení - Činnost - Program. Velké Meziřičči: Nákladem velkostatku Františka Harracha ve Velkém Meziř́ičí, 1931, $40 \mathrm{~s}$

[13] Lidové noviny ze 17. 6. 1930, s. 1-2.

[14] Velkomeziř́čsko z 21. 6. 1930, s. 7

[15] Velkomeziříčsko z 28. 6. 1930, s. 1-2.

[16] Československýzzemědělec z 8. 7. 1938, s. 215-216.

[17] KOSTOMAROV, B. Rybářsko-hydrobiologická stanice Františka Harracha ve Velkém Meziříćí. Věstník Československé akademie zemědělské, 1930, roč. 6, s. 680-684.

[18] KŘíŽENECKÝ, J. František Harrach jako zakladatel Rybářsko-hydrobiologické stanice ve Velkém Meziříčí na Moravě. Věstník Československé akademie zemědělské, 1938, roč. 14, s. 253-257.

[19] Archiv Mendelovy univerzity v Brně, fond Jaroslav Kř́řzenecký, inv. č. 69/16, karton 7 (rozhlasové přednášky).

[20] NOWAK, W. Rybářsko-hydrobiologická stanice Františka Harracha ve Velkém Meziříčí. In: Horácko Velké Meziríćí: družstvo Horácko, 1938, s. 218-222.

[21] Lidové noviny ze 14. 12. 1935, s. 2.

[22] Velkomeziříčsko z 11. 3. 1939, s. 4.

[23] Velkomeziř́čško z 15. 4. 1939, s. 5.

[24] BAYER, E. První biologická stanice na Moravě. Věda př́rodní, 1926, roč. 7, s. 127-136.

[25] Biografickýslovník českých zemí. Sv. Bas-Bend, Praha: Libri, 2005, 110 s.

[26] SOUDEK, Š. Biologická stanice v Lednici. Př́roda, 1926, roč. 19, s. 41-47.

[27] KOSTOMAROV, B. a LOSOS, B. Čtyřicetileté výročí Biologické stanice Vysoké školy zemědělské v Brně v Lednici. Sborník Vysoké školy zemědělskév Brně, 1962, řada A, č. 3-4, s. 361-367.

[28] MIKOVCOVÁ, A. Podíl Vysoké školy zemědělské v Brně na rozvoji zemědělského pokroku v meziválečném Československu. In:Zemědělskéškolství, výzkum a osvěta jako předpoklad hospodářského a sociálního rozvoje venkova v 19. a 20. století. Uherské Hradiště: Slovácké muzeum, 2004, s. 97-109.
Autor

Mgr. Aleš Vyskočil, Ph.D. ${ }^{1,2}$

凶vyskocil@brno.avcr.cz

'Výzkumný ústav vodohospodářský T. G. Masaryka, v. v. i., pobočka Brno ${ }^{2}$ Historický ústav Akademie věd ČR

Přispěvek prošel lektorským řizením.

\section{THE FIRST CZECHOSLOVAK REPUBLIC HYD- ROBIOLOGICAL STATIONS - THE BEGINNINGS OF SCIENTIFIC FISH RESEARCH IN MORAVIA}

\section{VYSKOCIL, A. ${ }^{1,2}$}

'TGM Water Research Institute, p.r.i., Brno Branch ${ }^{2}$ Institute of History of the Czech Academy of Sciences

Keywords: fisheries - fishponds - research - hydrobiological stations history - Czechoslovakia 1918-1945 - Lednice - Velké Meziříčí

Field stations represent one of the forms of fishery or fishpond research. Their origins can be found at the end of the $19^{\text {th }}$ century, but this type of research program flourished during the interwar era. At that time, two of the oldest and most important hydrobiological stations in Moravia - Lednice (1922) and Velké Meziríčí (1928) - were established. Both field stations were important centres of fishery and hydrobiological research in interwar Czechoslovakia and gained international reputation with their results. There was a personal connection of both stations with the educational and research institutes important at those times. In Velké Meziříčí, the research focused on the practical use of scientific knowledge (especially in the field of carp farming) and was closely related to the private statuses of the institution. In contrast, the research focus of the Lednice station was wider, covering the entire spectrum of branches of natural sciences. At the same time, this station operated in close cooperation with the university environment and had the statuses of educational research institute. 